\title{
FAKTOR-FAKTOR YANG MEMPENGARUHI SERVICE PER CONCEPTION PADA SAPI KRUI DI KECAMATAN PESISIR SELATAN
}

\author{
Factors Affecting Service per Conception of Krui Cattle in Pesisir Selatan District \\ Nur Fadilah Rizki Fauzi, Madi Hartono, Siswanto, Sri Suharyati \\ Departement of Animal Husbandry, Faculty of Agriculture, University of Lampung \\ Jl. Prof. Dr. Soemantri Brojonegoro No.1 Gedong Meneng Bandar Lampung 35145 \\ e-mail : nurfadilah1166@gmail.com
}

\begin{abstract}
Research on service per conception (S/C) of Krui Cattles in Pesisir Selatan Regency was carried out in December 2019 using two inseminators collection data, 75 farmers and 166 Krui Cattles that have been artificially inseminated. The purpose of this study was to determine: 1) the S/C value of Krui cattle in the Pesisir Selatan District, 2) the factors and its magnitude that influence the S/C of Krui cattle in Pesisir Selatan Regency. Data was analysed with multiple regression using SPSS (Statistical Package for Social Science) programs. The results showed that the $\mathrm{S} / \mathrm{C}$ value of Krui Cattles in Pesisir Selatan Regency was $1.53 \pm 0.71$. The factors that affected the $\mathrm{S} / \mathrm{C}$ value of Krui Cattless in Pesisir Selatan Regency were derived from the variable of farmers and livestock. At the farmer level the factors that influence wee the type of forage that is negatively associated with a factor of 0.229 , the shape of the cage wall which is negatively associated with 0.287 , and the sanitation of the cage that is negatively associated with 0.355 . Factors influencing $\mathrm{S} / \mathrm{C}$ values at the livestock level were negative associated body condition scores (BCS) of 0.429 , age of first mated was negative associations of 0.039 , and estrus postpartum negative associations of 0.118 .
\end{abstract}

Keywords: Factors and factors value, Service per conception, Krui cattle

\section{ABSTRAK}

Penelitian mengenai service per conception (S/C) pada Sapi Krui di Kecamatan Pesisir Selatan dilaksanakan pada Desember 2019 dengan 2 inseminator , 75 peternak dan 166 ekor Sapi Krui yang telah diIB. Tujuan penelitian ini adalah untuk mengetahui : 1) nilai S/C Sapi Krui di Kecamatan Pesisir Selatan, 2) faktor dan besar faktor yang memengaruhi S/C pada Sapi Krui di Kecamatan Pesisir Selatan. Data diolah menggunakan regresi berganda dan diolah dalam program SPSS (Statistics Packet for Social Science). Hasil penelitian menunjukkan bahwa nilai S/C pada Sapi Krui di Kecamatan Pesisir Selatan 1,53 $\pm 0,71$ Faktor-faktor yang memengaruhi nilai S/C pada Sapi Krui di Kecamatan Pesisir Selatan berasal dari variabel peternak dan ternak. Pada tingkat peternak faktor-faktor yang memengaruhi adalah jenis hijauan yang berasosiasi negatif dengan besar faktor 0,229, bentuk dinding kandang yang berasosiasi negatif sebesar 0,287 , dan sanitasi kandang yang berasosiasi negatif sebesar 0,355. Faktor yang memengaruhi nilai $\mathrm{S} / \mathrm{C}$ pada tingkat ternak adalah body condition score (BCS) yang berasosiasi negatif sebesar 0,429, umur pertama kali dikawinkan berasosiasi negatif sebesar 0,039, dan birahi postpartum berasosiasi negatif sebesar 0,118 .

Kata Kunci : Faktor dan besar faktor, Service per conception, Sapi Krui

\section{PENDAHULUAN}

Konsumsi daging sapi yang meningkat setiap tahunnya menjadikan sektor peternakan sapi perlu untuk dikembangkan lebih luas. Peningkatan konsumsi produk peternakan per kapita per tahun khususnya daging sapi mengalami peningkatan pada tahun 2017 menjadi 0,469 kg. Hal ini merupakan peningkatan yang cukup baik karena pada tahun 2013 dan 2014 konsumsi daging sapi tidak mengalami peningkatan dengan jumlah konsumsi sebesar $0,261 \mathrm{~kg}$ per kapita pertahun dan pada tahun 2015 mengalami peningkatan menjadi 0,417 meskipun pada tahun 2016 masih menunjukkan angka yang sama (Dirjen PKH, 2018). Peningkatan konsumsi ini didasari oleh kesadaran akan pentingnya protein hewani, peningkatan jumlah penduduk, dan peningkatan pendapatan penduduk. Daging sapi menjadi salah satu sumber protein hewani yang harus dicukupi kebutuhannya sehingga perlu ditingkatkan produktivitasnya.

Salah satu cara yang dapat ditempuh untuk meningkatkan produksi daging dan pedet atau pedet adalah dengan memperbanyak jumlah sapi potong dan kualitas genetik ternak. Ini dapat dilakukan dengan menerapkan Inseminasi Buatan (IB) pada sapi, karena semen yang 
digunakan untuk IB berasal dari sapi jantan yang memiliki genetik baik dan menghasilkan angka s/c dengan rata-rata lebih kecil dari kawin alami.

Sebagian besar sapi-sapi di Kabupaten Pesisir Barat adalah sapi lokal yang dinamakan Sapi Krui. Sapi Krui dipelihara secara semi intensif, pada pagi hari digembalakan dan pada sore hari dikandangkan (Fitrianingsih et al., 2017). Sapi Krui memiliki ukuran tubuh yang relatif kecil dibandingkan bangsa sapi lainnya namun mampu bertahan hidup pada suhu lingkungan yang tinggi dan pakan berkualitas rendah. Menurut Dinas Pertanian Kabupaten Pesisir Barat populasi sapi Krui yang berumur 1 sampai 2 tahun di Kecamatan Pesisir Selatan pada tahun 2019 sebanyak 2.379. Hal ini menjadikan Sapi Krui memiliki probabilitas yang tinggi untuk dikembangkan lebih lanjut dengan meningkatkan produktivitasnya sebagai salah satu sumber daya genetik lokal.

Berdasarkan habitat aslinya Sapi Krui memiliki lingkungan yang mendukung untuk pengembangan lebih besar. Kabupaten Pesisir Barat memiliki potensi yang cukup baik untuk menjadi tempat pengembangan populasi Sapi Krui. Pengembangan produktivitas Sapi Krui perlu memperhatikan aspek reproduksinya salah satunya angka service per conception (S/C). Service per conception $(\mathrm{S} / \mathrm{C})$ adalah penilaian atau perhitungan jumlah pelayanan (service) inseminasi buatan (IB) yang dibutuhkan oleh seekor betina sampai terjadi kebuntingan (Toelihere, 1993). Angka S/C dapat dijadikan salah satu acuan untuk meningkatkan produktivitas Sapi Krui, semakin rendah nilai $\mathrm{S} / \mathrm{C}$ maka semakin baik reproduksi dari sapi tersebut.

Menurut Haryanto et al. (2015), Sapi Bali di Kabupaten Pringsewu memiliki rata-rata nilai S/C 1,79 sedangkan Anggraini et al. (2016) menunjukkan nilai S/C pada sapi PO di Desa Sriwedari Kecamatan Tegineneng Kabupaten Pesawaran sebesar 2,07.

\section{MATERI DAN METODE}

\section{Waktu dan Tempat}

Penelitian ini dilaksanakan pada Desember 2019, pada inseminator, peternak dan ternak Sapi Krui sebagai objek pengamatan yang ada di Kecamatan Pesisir Selatan Kabupaten Pesisir Barat, Provinsi Lampung.

\section{Bahan dan Alat}

Ternak yang digunakan sebagai obyek penelitian ini adalah 166 ekor Sapi Krui betina yang berumur lebih dari 2 tahun, diinseminasi buatan, dan dipelihara minimal 2 tahun di
Kecamatan Pesisir Selatan Kabupaten Pesisir Barat, 75 orang peternak dan 2 orang inseminator sebagai objek yang diamati pada penelitian ini. Peralatan yang digunakan dalam penelitian ini adalah kuisioner untuk inseminator, kuisioner peternak dan kuisioner ternak yang berada di Kecamatan Pesisir Selatan, timbangan, termometer bola basah bola kering, alat tulis, dan kamera.

\section{Metode Penelitian}

\section{Teknik pengambilan sampel}

Metode yang digunakan dalam penelitian ini adalah metode survey dan data diperoleh dengan cara sensus. Data yang digunakan adalah data primer dan sekunder, data primer berupa hasil pengamatan ternak dan manajemen pemeliharaan, serta hasil wawancara pada peternak dan inseminator. Data sekunder berupa data akseptor yang diperoleh dari recording inseminator.

\section{Variabel yang digunakan}

Variabel dependen yang digunakan pada penelitian ini adalah service per conception pada Sapi Krui. Variabel independen untuk inseminator adalah (X1) pendidikan inseminator, (X2) lama menjadi inseminator, (X3) jumlah akseptor, (X4) jarak menuju akseptor, (X5) produksi straw, (X6) lama thawing, (X7) ketepatan waktu pelayanan IB. Variabel independen untuk peternak dan ternak adalah (X8) alasan beternak, (X9) pernah mengikuti pelatihan di bidang peternakan, (X10) pendidikan peternak, (X11) lama beternak, (X12) pengetahuan beternak, (X13) pengetahuan deteksi birahi, (X14) frekuensi pemberian hijauan, (X15) jenis hijauan, (X16) jumlah pemberian hijauan, (X17) jumlah konsentrat, (X18)sistem pemberian air minum, (X19) jumlah pemberian air minum, (X20) letak kandang, (X21) bentuk dinding kandang, (X22) bahan atap kandang, (X23) bahan latai kandang, (X24) luas kandang, (X25) sanitasi kandang, (X26) umur sapi, (X27) skor kondisi tubuh, (X28) umur pertama kali dikawinkan, (X29) birahi pertama setelah kelahiran, (X30) perkawinan postpartum, (X31) gangguan reproduksi, (X32) status reproduksi, (X33) pemeriksaan kebuntingan, dan usia penyapihan (X34).

\section{Pelaksanaan Penelitian}

Teknis pelaksanaan penelitian ini adalah mengumpulkan data sekunder dari recording, untuk mengetahui jumlah Sapi Krui yang diIB; melakukan sensus sapi yang digunakan sebagai sampel penelitian; mengumpulkan data primer, dengan cara pengisian kuisioner dengan cara mewawancarai peternak; mengamati manajemen 
pemeliharaan Sapi Krui di lokasi penelitian; menghitung nilai service per conception pada sapi Krui di lokasi penelitian.

\section{Analisis data}

Analisis data yang digunakan dalam penelitian ini adalah analisis regresi berganda. Sebelum dilakukan analisis data, dilakukan pengkodean terhadap data peternak dan ternak untuk memudahkan analisis yang kemudian diolah dalam program SPSS 2016 (statistic packet for social science). Variabel dengan nilai $\mathrm{P}$ terbesar dikeluarkan dari penyusunan model kemudian dilakukan analisis kembali sampai didapatkan model dengan nilai $\mathrm{P} \leq 0,10$ (Sarwono, 2006).

\section{HASIL DAN PEMBAHASAN}

\section{A. Kondisi Inseminator, Peternak, dan Ternak Sapi Krui di Kecamatan Pesisir Selatan}

Hasil penelitian yang dilakukan dengan metode survey dengan teknik pengambilan data secara sensus diperoleh 2 orang inseminator, 75 peternak dan 166 ekor ternak Sapi Krui yang di Inseminasi Buatan. Pada tingkat inseminator terdapat 1 orang yang bekerja sebagai inseminator dan 1 orang bekerja sebagai Tenaga Harian Lepas (THL). Pada tingkat pendidikan inseminator terdapat 1 orang inseminator yang lulus Sekolah Menengah Atas (50\%) dan 1 orang lulus sarjana $(50 \%)$. Rata-rata lama menjadi inseminator selama $4 \pm 2,828$ tahun. Rata-rata akseptor setiap bulannya sebanyak 30 ekor. Rata-rata jarak menuju akseptor adalah $20 \mathrm{~km}$. Straw yang digunakan untuk inseminasi buatan berasal dari BIBD Poncowati (50\%), BIB Lembang (25\%), dan BIB Singosari (25\%). Rata-rata lama thawing yang dilakukan oleh inseminator adalah $20 \pm 14,1421$ detik. Rata-rata ketepatan waktu pelaksanaan IB dari kedua inseminator adalah 77,5\%. Straw yang digunakan untuk IB adalah straw jenis Brahman $(50 \%)$ dan Simmental (50\%). Jenis kontainer yang digunakan oleh inseminator adalah jenis kontainer $\mathrm{DR}_{2}$. Cara penyimpanan yang dilakukan oleh inseminator menggunakan $\mathrm{DR}_{2}$ (50\%) dan Kontainer Deppo (50\%). Semua inseminator menanyakan waktu birahi sapi sebelum melakukan IB dan melakukan pemeriksaan kebuntingan.

Pada pengamatan tingkat peternak sebanyak 70 orang $(93,33 \%)$ memelihara ternak sebagai tabungan dan sebanyak 5 orang $(6,67 \%)$ memelihara ternak sebagai pekerjaan pokok. Peternak Sapi Krui tidak pernah mengikuti kursus atau pelatihan khusus untuk bidang peternakan. Tingkat pendidikan peternak Sapi Krui dimulai dari tingkat Sekolah Dasar sebanyak 29 orang (38,67\%), Sekolah Menengah Pertama sebanyak 21 orang (28\%), dan Sekolah Menengah Atas sebanyak 25 orang (33,33\%). Rata-rata peternak sudah beternak selama $7 \pm 4,24$ tahun. Sebanyak 67 orang $(89,33 \%)$ peternak mendapatkan pengetahuan beternak dengan cara turun-temurun, sisanya 8 orang $(10,67 \%)$ mendapatkan pengetahuan beternaknya dari belajar, dan seluruh peternak telah mengetahui cara deteksi birahi dengan baik. Sebanyak 39 peternak (52\%) memberikan hijauan satu kali perhari, 27 peternak (36\%) memberikan hijauan dua kali perhari, 2 peternak (2,7\%) memberikan hijauan tiga kali perhari, dan 7 peternak $(9,3 \%)$ ternaknya hanya digembalakan tanpa adanya pemberian hijauan tambahan. Rata-rata jenis hijauan yang diberikan adalah rumput lapang oleh 72 orang peternak (96\%), rumput gajah dan rumput lapang oleh 2 orang peternak $(2,67 \%)$ dan seorang peternak yang memberikan rumput lapang dan odot pada ternaknya $(1,33 \%)$. Rata-rata pemberian hijauan kepada ternak setiap harinya sebanyak $15 \pm 7,3 \mathrm{~kg}$ dan rata-rata pemberian konsentrat yang dilakukan adalah sebanyak $0,68 \pm 1,09 \mathrm{~kg}$ per harinya. Sistem pemberian air minum yang dilakukan di Pesisir Selatan menunjukan sebanyak 9 orang peternak (12\%) memberikan air minum pada ternaknya dengan cara adlibitum dan sebanyak 66 orang peternak (88\%) memberikan air minum pada ternaknya dengan menggunakan sistem libitum dengan rata-rata jumlah pemberian sebanyak 9,8 $\pm 4,8$ liter per hari. Bentuk dinding kandang yang dimiliki oleh peternak dibedakan menjadi tiga jenis yakni dinding terbuka digunakan oleh 56 orang $(74,67 \%)$, bentuk dinding tertutup oleh 6 orang peternak $(8 \%)$ dan sisanya peternak tidak memiliki kandang sebanyak 13 orang peternak. Bahan atap yang digunakan oleh peternak adalah sebagai berikut : peternak dengan bahan atap seng sejumlah 18 orang (24\%), genteng 37 orang $(49,33 \%)$, asbes 7 orang $(9,33 \%)$ dan tanpa atap karena tidak memiliki kandang sebanyak 13 orang peternak (17,33\%). Peternak yang menggunakan tanah sebagai lantai kandangnya sebanyak 50 orang $(66,67 \%)$, tanah 12 orang $(16 \%)$, dan 13 orang tidak memiliki kandang $(17,33 \%)$. Rata-rata luas kandang yang dimiliki

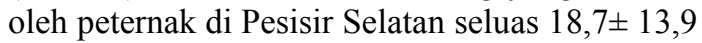
$\mathrm{m}^{2}$ dan sebanyak 20 peternak $(26,67 \%)$ melakukan sanitasi satu kali perharinya, 43 peternak $(57,33 \%)$ melakukan sanitasi sebanyak dua kali perhari, dan sisanya sebanyak 12 
peternak $(16 \%)$ peternak tidak melakukan sanitasi setiap hari.

Data ternak yang kami dapatkan adalah rata-rata umur ternak yang diteliti adalah $67,22 \pm 26,18$ bulan, body condition score (BCS) Sapi Krui dimulai dari BCS 2 sebanyak 44 ekor sapi (26,51\%), BCS 3 sebanyak 120 ekor $(72,29 \%)$, dan BCS 4 sebanyak 2 ekor $(1,2 \%)$, rata-rata lama waktu birahi pertama setelah melahirkan muncul adalah 2,67 $\pm 1,74$ bulan, dan rata-rata perkawinan postpartum juga menunjukkan angka yang sama 2,67 $\pm 1,74$ bulan. Gangguan reproduksi yang ada adalah abortus sebanyak 3 ekor sapi $(1,81 \%)$, hipofungsi sebanyak 1 ekor sapi $(0,06 \%)$, dan kejadian repeat breeder sebanyak 17 ekor sapi (10,24\%). Status reproduksi sapi betina di Pesisir Selatan adalah sebagai berikut: jumlah sapi induk sebanyak 142 ekor sapi $(85,54 \%)$ dan untuk sapi dara sebanyak 24 ekor sapi $(14,46 \%)$. Semua Sapi Krui yang di IB pernah diperiksa kebuntingannya. Berdasarkan hasil perhitungan didapatkan rata-rata nilai service per conception pada Sapi Krui adalah 1,53 $\pm 0,71$.

\section{B. Faktor-faktor yang Memengaruhi Service per Conception \\ Rata-rata nilai service per conception}

(S/C) Sapi Krui di Kecamatan Pesisir Selatan Kabupaten Pesisir Barat yaitu 1,53 $\pm 0,71$. Nilai $\mathrm{S} / \mathrm{C}$ tersebut masuk dalam kategori baik karena lebih rendah dari yang disampaikan oleh Toelihere (1992) bahwa nilai S/C standar berkisar 1,6--2,00 apabila lebih rendah dari itu maka tingkat kesuburan sapi tersebut lebih baik. Berdasarkan penelitian yang dilakukan sebelumnya, nilai S/C dari sapi Bali dan PO yaitu: 1,42 pada sapi PO (Aryogi et al., 2006) dan 2,07 (Anggraini et al., 2016) serta 1,79 pada sapi Bali (Haryanto et al., 2015). Jika dibandingkan dengan penelitian yang dilakukan sebelumnya maka nilai S/C Sapi Krui lebih baik karena memiliki nilai yang lebih kecil. Nilai $\mathrm{S} / \mathrm{C}$ yang lebih kecil berarti bahwa tingkat efisiensi reproduksi yang dimiliki oleh Sapi Krui lebih baik jika dibandingkan dengan jenis sapi lain pada penelitian sebelumnya.

Faktor-faktor yang memengaruhi nilai S/C pada Sapi Krui di Kecamatan Pesisir Selatan berasal dari variabel peternak dan ternak berdasarkan analisis regresi berganda yang dilakukan menggunakan SPSS adalah sebagai berikut : pada tingkat peternak faktor-faktor yang memengaruhi adalah jenis hijauan yang berasosiasi negatif dengan besar faktor 0,229, bentuk dinding kandang yang berasosiasi negatif sebesar 0,287, dan sanitasi kandang yang berasosiasi negatif sebesar 0,355 . Faktor yang memengaruhi nilai $\mathrm{S} / \mathrm{C}$ pada tingkat ternak adalah body condition score (BCS) yang berasosiasi negatif sebesar 0,429 , umur pertama kali dikawinkan berasosiasi negatif sebesar 0,039 , dan birahi postpartum berasosiasi negatif sebesar 0,118 .

Persamaan regresi pada tingkat peternak dan ternak adalah

$\mathrm{Y}=5,187-0,229(\mathrm{X} 15)-0,287(\mathrm{X} 21)-0,355$

$(X 25)-0,429(X 27)-0,039(X 28)-0,118$

(X29)

Keterangan :

$\mathrm{Y}:$ : nilai Service per conception

X15 : jenis hijauan

X21 : bentuk dinding kandang

X25 : sanitasi kandang

$\mathrm{X} 27$ : body condition score

X28 : umur pertama kali dikawinkan

X29 : birahi postpartum

Faktor-faktor yang berpengaruh pada s/c ditentukan berdasarkan angka signifikansi yang terdapat pada hasil analisis regresi berganda yang dilakukan pada SPSS, angka signifikansi dibawah 0,1 menunjukan variabel yang berpengaruh. Faktor-faktor seperti pendidikan inseminator, lama menjadi inseminator, jumlah akseptor, jarak menuju akseptor, produksi straw, lama thawing, ketepatan IB, alasan beternak, pernah mengikuti kursus, pendidikan peternak, lama beternak, pengetahuan beternak, pengetahuan deteksi birahi, frekuensi pemberian hijauan, jumlah konsentrat, sistem pemberian air minum, letak kandang, bahan atap, bahan lantai kandang, luas kandang, umur sapi, perkawinan postpartum, gangguan reproduksi, status reproduksi, pemeriksaan kebuntingan dan umur penyapihan tidak memiliki pengaruh terhadap nilai service per conception pada Sapi Krui di Kecamatan Pesisir Selatan. Berikut ini adalah faktor-faktor dan besar faktor yang memengaruhi nilai s/c sapi Krui berdasarkan hasil analisis regresi berganda yang dihitung menggunakan SPSS :

\section{Jenis hijauan}

Jenis hijauan bermakna $(\mathrm{P}=0,028)$ yang berarti signifikan dan berasosiasi negatif dengan besar faktor 0,229 atau dapat berpengaruh sebesar 22,9\% dalam menurunkan nilai S/C yang berarti bahwa semakin baik kualitas dari hijauan yang diberikan akan menurunkan nilai $\mathrm{S} / \mathrm{C}$ dikarenakan kualitas hijauan yang diberikan akan memengaruhi kandungan nutrisi yang lebih baik sehingga mampu memenuhi kebutuhan hidup pokok Sapi Krui dan mengoptimalkan siklus reproduksinya. Apabila kebutuhan hidup pokok ternak sudah terpenuhi maka hal tersebut tidak akan mengganggu performa reproduksi Sapi 
Krui. Salah satu faktor yang mempengaruhi kondisi reproduksi induk adalah ketersediaan protein yang cukup sebagai sumber nutrisi, sehingga dapat mempengaruhi kecepatan berahi sapi Bali induk untuk kebutuhan fungsional reproduksi. Hubungan antara jumlah protein kasar dan timbulnya estrus postpartus telah dikemukakan oleh Sasser, et al. (1988). Jenis hijauan yang dikonsumsi oleh Sapi Krui di Kecamatan Pesisir Selatan adalah Rumput Lapang (96\%), Rumput Gajah (2,67\%), dan Rumput Odot (1,33\%).

Berdasarkan jenis hijauan yang digunakan, jenis hijauan yang memiliki kandungan nutrisi paling baik adalah Rumput Odot dengan kandungan nutrisi sebagai berikut :LK daun $2,72 \%$, LK batang $0,91 \%$, PK daun 14,35\%, dan PK batang 8,10\% (Yassin et al., 2003). Sedangkan kandungan nutrisi Rumput Lapang menurut Herman (1989) adalah sebagai berikut BK 78,37\%, PK 7,12\%, SK 27,59\%, LK 0,91\%, BETN 35,61\%, dan TDN 54,29\%. Jika dihubungkan dengan hasil analisis maka Rumput Odot lebih berpengaruh untuk menurunkan nilai S/C Sapi Krui karena memiliki nilai nutrisi yang lebih baik.

Menurut Adrial (2010) sapi Krui memiliki kemampuan adaptasi yang tinggi terhadap lingkungan dan hijauan dengan kandungan nutrisi yang rendah. Sapi Krui masih bisa menunjukkan performa reproduksi yang baik meskipun hijauan yang dikonsumsi memiliki kandungan nutrisi yang rendah seperti rumput lapang dan rumput gajah jika dibandingkan dengan kandungan nutrisi rumput odot. Kandungan nutrisi yang dimiliki oleh Rumput Odot yang lebih baik diharapkan dapat meningkatkan efisiensi reproduksi dengan cara menurunkan nilai S/C. Efisiensi reproduksi sapi dipengaruhi oleh banyak hal salah satunya yaitu kebutuhan nutrisi. Menurut Pradhan (2008) kesuburan reproduksi ternak dipengaruhi oleh nutrisi yang diperoleh ternak dan berperan penting dalam siklus reproduksi.

Schillo (1992) menambahkan bahwa apabila nutrisi dari induk sapi tidak terpenuhi maka akan mengganggu siklus reproduksi sapi berupa terlambatnya estrus postpartum yang dapat mengurangi efisiensi reproduksi yang disebabkan oleh kurangnya produksi Leuteinizing hormone yang berfungsi untuk memunculkan estrus postpastum dengan mekanisme merangsang pertumbuhan folikel. Kekurangan nutrisi juga dapat menyebabkan hipofungsi ovarium.

Adrial (2010) menyatakan meskipun dengan jumlah nutrisi yang tidak terlalu tinggi Sapi Krui tetap bisa menunjukkan performa reproduksi yang cukup baik hal ini dikarenakan sifat adaptasinya yang baik terhadap lingkungan maupun hijauan dengan kadar nutrisi rendah. Oleh karena itu, penggunaan Rumput Odot yang memiliki kualitas lebih baik dari segi nutrisi jika dibandingkan dengan Rumput Lapang sebagai hijauan yang dikonsumsi oleh Sapi Krui harus ditingkatkan jumlah penggunaannya untuk menghasilkan S/C yang lebih baik.

\section{Bentuk dinding kandang}

Bentuk dinding kandang bermakna $(\mathrm{P}=0,021)$ signifikan dan berasosiasi negatif terhadap $\mathrm{S} / \mathrm{C}$ dengan faktor yang memengaruhi sebesar 0,287 yang berarti bahwa bentuk dinding kandang dapat menurunkan nilai $\mathrm{s} / \mathrm{c}$ sebesar $28,7 \%$. Bentuk dinding yang digunakan oleh peternak di Kecamatan Pesisir Selatan adalah bentuk dinding terbuka $(74,67 \%)$, bentuk dinding tertutup (8\%), dan sisanya sebanyak $(17,33 \%)$ tidak memiliki kandang. Pada variabel ini berarti bahwa semakin banyak kandang yang menggunakan jenis dinding terbuka dapat menurunkan nilai $\mathrm{S} / \mathrm{C}$ jika dibandingkan dengan bentuk dinding tertutup. Bentuk dinding terbuka memiliki sirkulasi udara yang lebih baik jika dibandingkan dengan bentuk dinding tertutup. Bentuk dinding terbuka memudahkan pengawasan deteksi birahi yang dapat meningkatkan ketepatan IB yang dilakukan, sehingga nilai S/C dari Sapi Krui menjadi rendah dan penggunaan tipe dinding terbuka lebih memudahkan peternak untuk membersihkan kandangnya. Kondisi kandang yang bersih akan mencegah tumbuhnya bakteri patogen yang dapat mengganggu kesehatan ternak dan merugikan dari segi reproduksi.

Menurut Bakri dan Sapirinto (2015), keuntungan dinding kandang terbuka dapat memperlancar pergantian udara dan memberi kesempatan masuknya sinar matahari ke dalam kandang.

Penelitian Febrianthoro et al. (2015) menunjukkan bahwa penggunaan dinding kandang tertutup menyebabkan kurangnya sirkulasi pertukaran udara yang baik serta kurang mendapatkan sinar matahari, sehingga lantai kandang lebih lembab dan keadaan ini dapat meningkatkan kemungkinan munculnya penyakit dan mengganggu kesehatan ternak.

\section{Sanitasi kandang}

Sanitasi kandang bermakna $(\mathrm{P}=0,000)$ signifikan dan berasosiasi negatif terhadap $\mathrm{S} / \mathrm{C}$ dengan faktor sebesar 0,355 atau sanitasi kandang dapat menurunkan nilai s/c sebanyak 35,5\%. Hal ini berarti makin sering sanitasi dilakukan dan makin bersih keadaan kandang maka akan menurunkan nilai S/C Sapi Krui. 
Sebanyak 20 peternak $(26,67 \%)$ melakukan sanitasi satu kali per harinya, 43 peternak $(57,33 \%)$ melakukan sanitasi dua kali perhari, dan 12 peternak (16\%) tidak melakukan sanitasi satu kali perhari. Sanitasi dilakukan oleh peternak biasanya pada sore hari atau pagi hari saat memberikan pakan pada sapi.

Jumlah sanitasi yang dilakukan oleh peternak dapat berpengaruh pada nilai $\mathrm{S} / \mathrm{C}$ karena semakin sering sanitasi dilakukan maka keadaan kandang Sapi Krui lebih bersih dan kemungkinan munculnya bakteri patogen yang dapat mengganggu kesehatan dapat ditekan. Sesuai dengan pendapat Suharyati dan Hartono (2016) bahwa sanitasi juga dapat menjaga kesehatan sapi agar tidak mudah terserang penyakit. Kondisi kandang yang bersih juga akan memberikan rasa nyaman kepada Sapi Krui sehingga tingkat stres pada sapi menjadi rendah dan memberikan efek yang baik pada performa dari segi produksi maupun reproduksinya.

Menurut Hartono (1999), sanitasi kandang berpengaruh terhadap $\mathrm{S} / \mathrm{C}$, semakin bersih kandang maka nilai $\mathrm{S} / \mathrm{C}$ akan menurun. Apabila kandang kotor akan menyebabkan banyak kuman penyakit yang dapat menginfeksi ternak. Kondisi ternak yang sakit dapat memengaruhi nafsu makan menjadi menurun, hal ini dapat memengaruhi kondisi fisiologis tubuh termasuk gangguan reproduksi.

\section{Body condition score}

Body condition score (BCS) bermakna $(\mathrm{P}=0,000) \quad$ signifikan yang berasosiasi negatif terhadap S/C Sapi Krui dengan faktor yang memengaruhinya 0,429 atau faktor BCS dapat menurunkan nilai s/c sebesar $42,9 \%$ yang berarti bahwa semakin banyak sapi dengan angka BCS yang tinggi maka nilai S/C Sapi Krui semakin rendah. Berdasarkan penilaian BCS yang dilakuan pada sapi Krui didapatkan hasil bahwa nilai BCS sapi Krui dimulai dari BCS 2 sebanyak 44 ekor sapi $(26,51 \%)$, BCS 3 sebanyak 120 ekor $(72,29 \%)$, dan BCS 4 sebanyak 2 ekor $(1,2 \%)$. Body condition score dinilai menjadi alat praktis yang penting dalam menilai kondisi tubuh ternak dengan cara pengamatan visual dan perabaan pada timbunan lemak dibawah kulit sekitar pangkal ekor, tulang punggung, dan pinggul (Susilorini et al., 2007).

Berdasarkan penelitian ini BCS yang lebih tinggi dapat menurunkan $\mathrm{S} / \mathrm{C}$ dikarenakan pada sapi dengan BCS yang lebih tinggi menunjukkan bahwa sapi tersebut sudah terpenuhi kebutuhan nutrisi dan memiliki kesehatan yang baik, dengan kebutuhan nutrisi yang cukup sapi tersebut dapat menunjukkan performa produksi maupun reproduksinya tanpa harus mengganggu kebutuhan hidup pokok. Sapi dengan BCS yang rendah cenderung memiliki performa reproduksi yang kurang jika dibandingkan dengan sapi BCS tinggi. Sapi dengan BCS rendah tidak dapat menunjukkan performa sebaik sapi BCS tinggi karena kebutuhan hidup pokoknya belum terpenuhi sehingga performa produksi dan reproduksinya menjadi terhambat. Putro (2005) menyatakan bahwa sapi dengan BCS $<2,00$ cenderung akan menimbulkan keadaan hipofungsi ovarium, keadaan ini ditandai dengan ovarium yang mengecil, permukaan halus tanpa adanya folikel, sehingga akan memunculkan kondisi anestrus pada sapi yang akan berdampak pada performa reproduksi yang buruk.

Nilai S/C yang lebih rendah pada BCS yang lebih tinggi pada penelitian ini sesuai dengan pendapat Budiawan et al. (2015) yang menyatakan bahwa nilai $\mathrm{S} / \mathrm{C}$ lebih rendah pada BCS 2 dan 3 dibandingkan dengan BCS 4. Ratarata BCS Sapi Krui pada penelitian ini adalah BCS 3. Ternak yang kondisi tubuhnya sangat kurus memiliki cadangan lemak yang kurang, sehingga mengakibatkan rendahnya tingkat reproduksi sapi dan meningkatkan nilai $\mathrm{S} / \mathrm{C}$. BCS memiliki hubungan dengan reproduksi ternak seperti kesuburan, kebuntingan, proses kelahiran, laktasi, semua akan mempengaruhi sistem reproduksi. Apabila ternak memiliki bobot badan yang melebihi bobot badan ideal, ternak tersebut akan mengalami gangguan reproduksi dan penyakit metabolisme, sebaliknya apabila ternak memiliki bobot badan kurang dari ideal akan berdampak pada sistem reproduksi.

\section{Umur pertama kali dikawinkan}

Umur pertama kali dikawinkan bermakna $(\mathrm{P}=0,002)$ signifikan berasosiasi negatif terhadap $\mathrm{S} / \mathrm{C}$ dengan besar faktor yang memengaruhi 0,039 atau sebanyak $33,9 \%$ umur pertama kali dikawinkan dapat berpengaruh terhadap nilai s/c. Hal ini berarti bahwa semakin bertambahnya umur pertama kali dikawinkan maka nilai S/C Sapi Krui akan lebih baik. Ratarata umur pertama kali dikawinkan adalah $26,40 \pm 4,08$ bulan.

Semakin bertambahnya umur sapi pada saat pertama kali dikawinkan akan menurunkan nilai $\mathrm{S} / \mathrm{C}$ karena pada kondisi tersebut organ reproduksi sapi sudah berfungsi dengan baik dan sapi sudah dalam kondisi dewasa tubuh. Menurut Rianto dan Purbawati (2009), sebaiknya, sapi dara dikawinkan pertama kali pada umur 18--24 bulan. Pada umur tersebut, pertumbuhan tubuh sapi betina sudah mencapai optimum untuk mendukung perkembangan janin. Kondisi sapi yang sudah dewasa tubuh dapat 
mengurangi kemungkinan terjadinya kejadian kawin berulang yang sering muncul pada sapi dengan umur pertama kali dikawinkan lebih rendah. Munculnya kejadian kawin berulang ini akan menyebabkan tingginya nilai $\mathrm{S} / \mathrm{C}$ yang menjadikan performa reproduksi menjadi buruk.

Kejadian kawin berulang yang tinggi pada sapi yang perkawinan pertamanya lebih rendah ini sesuai dengan pendapat yang disampaikan oleh Hastuti et al. (2008) bahwa umur pertama kali dikawinkan berasosiasi negatif terhadap repeat breeder (RB), yang berarti semakin tinggi umur pertama kali sapi dikawinkan maka akan menurunkan kejadian RB. Turunnya kejadian RB ini juga akan menurunkan nilai $\mathrm{S} / \mathrm{C}$ sehingga reproduksi lebih efisien. Saladin (1983) menambahkan bahwa kawin berulang ini sering terdapat pada sapi muda sebagai akibat ovum yang dihasilkan ovariumnya banyak yang gagal menjadi telur yang baik sehingga belum dapat jadi atau terjadi pembuahan.

\section{Birahi postpartum}

Birahi post partum bermakna $(\mathrm{P}=0,000)$ signifikan berasosiasi negatif terhadap nilai $\mathrm{S} / \mathrm{C}$ dengan faktor sebesar 0,118 atau birahi post partum dapat memengaruhi nilai $\mathrm{s} / \mathrm{c}$ sebesar $11,8 \%$. Hal ini berarti semakin lama waktu munculnya birahi postpartum maka akan menurunkan nilai S/C. Rata-rata munculnya birahi postpartum selama 2,67 $\pm 1,74$ bulan.

Kejadian birahi postpartum yang lebih lama dengan kisaran rata-rata 2,67 $\pm 1,74$ bulan atau 80 hari menunjukkan pengaruh menurunkan nilai $\mathrm{S} / \mathrm{C}$ sebesar 0,118 . Sebelum munculnya birahi postpartum sistem reproduksi sapi akan melakukan involusi uteri atau mengembalikan uterus ke bentuk semula dan melakukan perbaikan tubuh pasca melahirkan. Sapi menunjukkan fase anestrus pasca melahirkan karena adanya penurunan berat badan akibat penggunaan cadangan lemak dan nutrisi yang dibutuhkan cukup banyak untuk perbaikan tubuh pasca melahirkan dan menyusui. Sapi dengan birahi postpartum yang lebih lama akan menunjukkan nilai $\mathrm{S} / \mathrm{C}$ yang lebih rendah dibandingkan dengan sapi yang birahi postpartumnya muncul lebih cepat karena sapi benar-benar dalam kondisi siap bunting periode berikutnya.

Berdasarkan kebutuhan nutrisi dan BCS sapi, sapi dengan $\mathrm{BCS}<2,00$ akan mengalami birahi postpartum yang lebih lama akibat hipofungsi ovaria. Oleh karena itu Sapi Krui dengan waktu birahi postpartum sebesar 80 hari dapat menurunkan $\mathrm{S} / \mathrm{C}$ dan masih dalam jangkauan normal karena baru dikatakan abnormal apabila melampaui waktu 90 hari menurut (Ahuja et al., 2005).

Crowe et al. ( 2014) menambahkan ovulasi sapi induk pasca beranak bisa mencapai 70--90 hari post partum apabila BCS rendah sekali. Sapi dengan kondisi badan bagus (sekitar 3,00) akan kembali estrus dalam waktu minimal, kurang dari skor itu akan membutuhkan waktu pulihnya siklus lebih lama

\section{Penerapan Model}

Penerapan model hasil analisis pada tingkat peternak dan ternak dengan nilai rata-rata kondisi nyata di lapangan adalah :

$$
\begin{aligned}
\mathrm{Y}= & 5,187-0,229(\mathrm{X} 15)-0,287(\mathrm{X} 21)-0,355 \\
& (\mathrm{X} 25)-0,429(\mathrm{X} 27)-0,039(\mathrm{X} 28)-0,118 \\
& (\mathrm{X} 29) \\
= & 5,187-0,229(1)-0,287(1)-0,355(2)- \\
& 0,429(3)-0,039(26,4)-0,118(2,67) \\
= & 5,187-0,229-0,287-0,71-1,287-1,029 \\
& -0,315 \\
= & 1,33
\end{aligned}
$$

Hasil diatas dapat diartikan bahwa bila jenis hijauan yang diberikan adalah rumput lapang, bentuk dinding terbuka, sanitasi kandang dilakukan sebanyak 2 kali, skor kondisi tubuh sapi 3, umur pertama kali dikawinkan 26,4 bulan dan birahi pertama setelah melahirkan 2,67 bulan maka nilai S/C pada Sapi Krui di Kecamatan Pesisir Selatan Kabupaten Pesisir Barat adalah 1,33. Selain itu, faktor-faktor yang memengaruhi S/C pada Sapi Krui di Kecamatan Pesisir Selatan yang berasal dari peternak dan ternak dapat dihitung dengan penerapan model keadaan ideal adalah

$$
\begin{aligned}
Y= & 5,187-0,229(\mathrm{X} 15)-0,287(\mathrm{X} 21)-0,355 \\
& (\mathrm{X} 25)-0,429(\mathrm{X} 27)-0,039(\mathrm{X} 28)-0,118 \\
& (\mathrm{X} 29) \\
= & 5,187-0,229(3)-0,287(1)-0,355(2)- \\
& 0,429(3)-0,039(24)-0,118(2) \\
= & 5,187-0,687-0,287-0,71-1,287-0,936- \\
& 0,236 \\
= & 1,044
\end{aligned}
$$

Hasil diatas dapat diartikan bahwa bila hijauan yang diberikan adalah rumput odot, dinding kandang terbuka, sanitasi kandang dilakukan 2 kali sehari, skor kondisi tubuh sapi 3, umur pertama kali dikawinkan 24 bulan, dan birahi postpartum 2 bulan maka nilai S/C Sapi Krui di Kecamatan Pesisir Selatan Kabupaten Pesisir Barat sebesar 1,044.

\section{Simpulan}

\section{SIMPULAN DAN SARAN}

Berdasarkan hasil penelitian pada inseminator, peternak, dan ternak di Kecamatan Pesisir Selatan Kabupaten Pesisir Barat dapat disimpulkan : 
1. service per conception $(\mathrm{S} / \mathrm{C})$ pada Sapi Krui di Kecamatan Pesisir Barat Kabupaten Pesisir Barat adalah 1,53 $\pm 0,71$

2. faktor-faktor yang memengaruhi nilai $\mathrm{S} / \mathrm{C}$ pada Sapi Krui di Kecamatan Pesisir Selatan Kabupaten Pesisir Barat pada tingkat peternak adalah jenis hijauan yang berasosiasi negatif dengan besar faktor 0,229, bentuk dinding kandang berasosiasi negatif dengan besar faktor 0,287, sanitasi kandang berasosiasi negatif dengan besar faktor 0,355 . Pada tingkat ternak adalah skor kondisi tubuh berasosiasi negatif dengan besar faktor 0,429, umur pertama kali dikawinkan berasosiasi negatif dengan besar faktor 0,039 , dan birahi pertama setelah kelahiran berasosiasi negatif dengan besar faktor 0,118 .

\section{Saran}

Dari hasil penelitian, penulis menyarankan kepada pemerintah terkait untuk memberikan pelatihan kepada peternak untuk meningkatkan pengetahuan tentang manajemen reproduksi, produksi, dan pakan yang baik dan benar.

\section{DAFTAR PUSTAKA}

Adrial. 2010. Sapi Lokal Kalimantan Tengah Sumberdaya Lokal Potensi Yang Belum Termanfaatkan Secara Optimal. Balai Pengkajian Teknologi Pertanian Kalimantan Tengah. Palangkaraya.

Ahuja C, and F. Montiel. 2005. Body condition and suckling as factors influencing the duration of postpartum anestrus in cattle: A Review. J. of Animal Science. 85 (1-2) : 1-26.

Anggraini, S., Sulastri, dan S. Suharyati. 2016. Status reproduksi dan output berbagai bangsa sapi di Desa Sriwedari, Kecamatan Tegineneng Kabupaten Pesawaran. J. Ilmiah Peternakan Terpadu. 4 (1) : 47-54.

Aryogi, P. W. Prihandini, dan D. B. Wijono. 2006. Pola Pembibitan sapi Potong Lokal Peranakan Ongole pada Kondisi Peternakan Rakyat. Loka Penelitian Sapi Potong Grati. Pasuruan.

Astuti, M. H. 2017. Service Per Conception in Beef Cattle with Artificial Insemination in Kapuas Basarang District of Central Kalimantan. J. of Health, Medicine and Nursing. 39 : 69-71.

Bakri dan Sapirinto. 2015. Sukses Bisnis dan Beternak Sapi Perah. Lily Publisher. Yogyakarta.
Budiawan, A., M. N. Ihsan, dan S. Wahjuningsih. 2015. Hubungan body condition score terhadap service per conception dan calving interval sapi potong peranakan. J. Ternak Tropika . 16 (1): 34-40.

Crowe, M.A., M. G. Diskin, and E. J. Williams. 2014. Parturition to resumption of ovarian cyclicity: Comparative aspects of beef and dairy cows. J. Animal Consortium. $8: 40-53$.

Direktorat Jenderal Peternakan dan Kesehatan Hewan. 2018. Statistik Peternakan dan Kesehatan Hewan. Kementrian Pertanian. Jakarta

Febrianthoro, F., M. Hartono, dan S. Suharyati. 2015. Faktor-faktor yang memengaruhi conception rate pada sapi Bali di Kabupaten Pringsewu. J. Ilmiah Peternakan Terpadu 3(4) : 239-244.

Fitrianingsih, S., Sulastri, M. D. I. Hamdani. 2017. Karakteristik kualitatif Sapi Krui di Kabupaten Pesisir Barat Lampung. J. Riset dan Inovasi Peternakan. 1(3) : 5-9.

Hartono, M. 1999. Faktor-faktor dan Analisis Garis Edar Selang Beranak pada sapi Perah di Kecamatan Musuk Kabupaten Boyolali. Tesis. Program Pasca Sarjana Universitas Gadjah Mada. Yogyakarta.

Haryanto, D., M. Hartono, dan S. Suharyati. 2015. Beberapa faktor yang mempengaruhi service per conception pada sapi Bali di Kabupaten Pringsewu. J. Ilmiah Peternakan Terpadu. 3 (3): 145-150.

Hastuti, D., S. Nurtini., dan R. Widiati. 2008. Kajian sosial ekonomi pelaksanaan inseminasi buatan sapi potong di Kabupaten Kebumen. J. Ilmu Pertanian. 4 (2) : 1-12.

Herman, R. 1989. Kualitas Karkas Domba Lokal Hasil Penggemukan. Proceeding Pertemuan Ilmiah Ruminansia (2). Jakarta.

Pradhan, R. 2008. Reproductive disorders in cattle due to nutritional status. J. of International Development and Cooperation. 14 (1): 45-66..

Rianto, E., dan E. Purbowati. 2009. Panduan Lengkap sapi Potong. Penerbit Penebar Swadaya. Jakarta.

Saladin, R. 1983. Penampilan Sifat-Sifat Reproduksi Dan Reproduksi sapi Lokal Pesisir Selatan di Provinsi Sumatera Barat. Disertasi. Program Pascasarjana IPB. Bogor. 
Sarwono, J. 2006. Analisis Data Penelitian Menggunakan SPSS. Penerbit Andi. Yogyakarta.

Sasser, R.E., R.J. William, R.C. Bull, C.A. Ruder and D.E Falk. 1988. Postpartum reproductive performance in crude protein restricted beef cows. University of Idaho, Moscow. J. Anim. Sci. 66: 3033-3039.

Schillo, K. K. 1992. Effect of dietary energy on control of Luteinizing hormone secretion in cattle and sheep. J. Animal Science. 70 (4) : 1.271--1.282.

Suharyati, S. dan M. Hartono. 2016. Pengaruh manajemen peternak terhadap efisiensi reproduksi sapi Bali di Kabupaten Pringsewu Provinsi lampung. J. Penelitian Pertanian Terapan. 16 (1) : 61-67.

Toelihere. 1993. Inseminasi Buatan Pada Ternak. Angkasa. Bandung.

Yassin, M., M. A. Malik, and M. S. Nazir. 2003. Effect of different spatial arrangements on forage yield, yield, components and quality of mott elephant grass. J. Agron. 2:52-58. 